\title{
3. CASHFIELDS SHOPPING CENTRE: CHRISTCHURCH
}

\section{J.M. Taylor*}

\section{DESCRIPTION OF BUILDING:}

The building was originally designed as a department store for the D.I.C. Limited and was constructed in three stages commencing in the early 1890 's. It is of 3 storeys with a basement over part of the area. Walls are of brick masonry, and floors and roof are timber framed on steel beams and cast iron columns.

The general layout of the structure is shown in fig. 1. The building extends the full depth of the city block - some $10 \mathrm{~lm}$ - with width $2 \mathrm{~lm}$ (approx.) at Cashel Street, and $37 \mathrm{~m}$ (approx.) at Lichfield Street. Storey heights are $5.5 \mathrm{~m}$ ground to first floor, $4.8 \mathrm{~m}$ first to second and $4.0 \mathrm{~m}$ second floor to roof. Parapets are $1.2 \mathrm{~m}$ high at side walls and up to $3.0 \mathrm{~m}$ high at the street frontages.

The building was generally in sound condition, with no sign of any significant deterioration or movement in the main structural elements. Floor ties to the side walls could be observed externally at all levels, although the spacing at the second floor and roof was sparse and irregular.

\section{DEVELOPMENT SCHEME:}

The development plan was for a shopping mall at ground floor level and further retail premises at first floor and on a new mezzanine over part of the area. In addition to the earthquake consideration of the new mezzanine floors, new stairway, new street verandahs and a bridge at first floor level to adjacent premises.

The work was carried out in 1979/80.

\section{LOCAL BODY REQUIREMENTS:}

When a building permit application is made for alterations to an existing building, the Christchurch City Council will generally apply the following requirements related to earthquake resistance:

(a) There must be no reduction in the overall strength of the building.

(b) Any alterations or repairs must comply with the by-laws as far as is reasonably possible.

(c) Any building not having "moderate" earthquake resistance and constituting a danger, must be secured or taken down under section $301 \mathrm{~A}$ of the Municipal Corporations Act.

The minimum design standard is

*Partner, Halliday, O'Loughlin \& Taylor, Consulting Engineers, Christchurch strengthening, the structural work included

therefore the "moderate" earthquake as defined in the Act.

The building had been unoccupied for some months before a sale was finalised, and the City Council had made it clear to prospective purchasers that they would consider serving notice under the Municipal Corporations Act unless the purchaser proceeded to:

(a) Remove or strengthen parapets before re-occupation.

(b) Write to the Council agreeing to either -

(i) Institute a 5 year strengthening programme commencing not later than 1981, or

(ii) Demolish the building by 1983 .

The Council's general requirements were therefore quire clear, and discussion with Council officers at an early stage clarified the specific interpretations and applications for this project.

\section{DESIGN PHILOSOPHY :}

The economic viability of the project required selection of the earthquake loadings to give a socially acceptable level of protection against loss of life, rather than specifically limiting damage to property. The New Zealand Parliament in enacting section $301 \mathrm{~A}$ of the Municipal Corporations Act have determined this level to be the "moderate" earthquake as defined in the Act. Note the emphasis in the Act on protection of persons. Decisions on the level of protection to property are left to the property owner.

The decision was therefore made to strengthen the building to the minimum standard required by the Act and by the City Council - namely $50 \%$ of the loads required by design code NZSS.1900, Chapter 8: 1965. For Christchurch, this standard is regarded as being adequate for an earthquake of intensity MM7, with a probable return period of some 50 years.

Existing masonry elements were checked for this loading using seismic force factors of up to 4 for face loaded walls, and 6 for cantilevered parapets. Allowable stresses adopted were $.05 \mathrm{MPa}$ for shear and $0.7 \mathrm{MPa}$ for axial load, with no tension permitted under combined axial load and bending.

While any calculations related to the existing structure are of necessity based on approximations and assumptions, a conscientious and reasonably conservative analysis is likely to considerably under-estimate its capacity. It is interesting to note that the Cashfields building has already withstood earthquakes of assessed intensity MM7.6 and MM8 without

BULLETIN OF THE NEW ZEALAND NATIONAL SOCIETY FOR EARTHQUAKE ENGINEERING, VOL. 16, NO. 2, JUNE 1983 
visible damage.

STRENGTHENING PROCEDURES:

Initial appraisal of the building indicated the following areas of particular concern:

1. The absence of any lateral load resisting elements near the ends of the building.

2. The stability of the parapets, especially those on street frontages.

3. The capacity of the floor and roof diaphragms and their connections to the walls.

\section{Lateral Load Frames -}

Seven reinforced concrete half frames were constructed to provide additional lateral load capacity

(see figs. $1 \& 2$ ). The location and configuration of the frames were chosen to take maximum advantage of the existing vertical load carrying elements, and to simplify construction as much as possible within the constraints of the architectural requirements.

\section{Parapets -}

The front wall parapets were tied back to the roof diaphragm with raking steel struts, located to match external piers in the facade.

The side wall parapets also had raking struts back to the roof diaphragm, and with continuous mild steel flats epoxy bonded to each face of the parapet to provide composite action.

\section{Floor and Wall Ties -}

New mild steel wall ties were installed at external walls to increase the capacity of the connection between the walls and the floor and roof diaphragms. In addition, ties were provided at intervals to connect the ends of the floor joists across the main floor beams. For ease of installation, the ties were chased into the flooring, and consisted of steel dowels into the joists, accurately located using a template. (see fig. 3.)

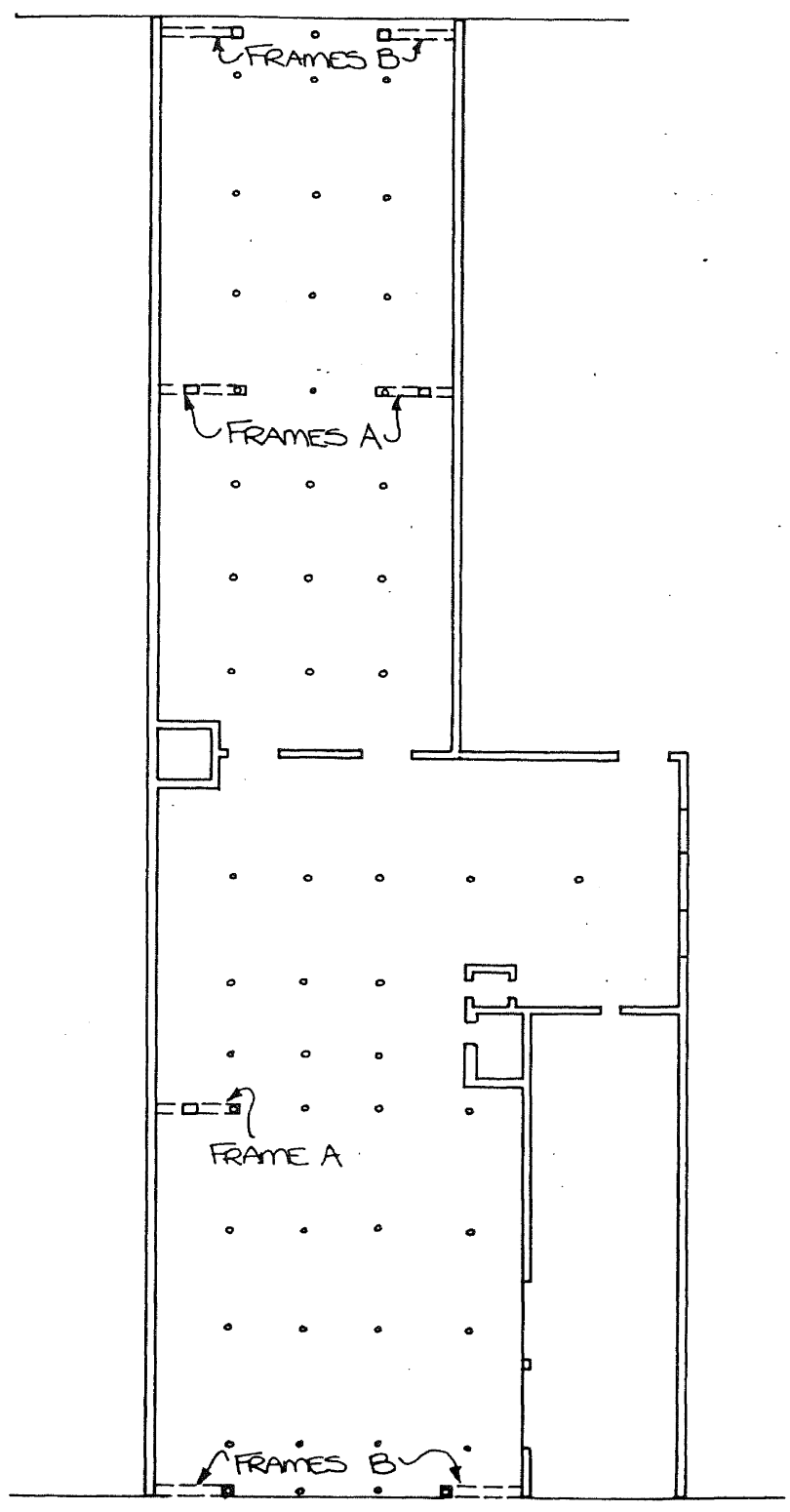

GROUND FOOR PLAN 


\section{4}

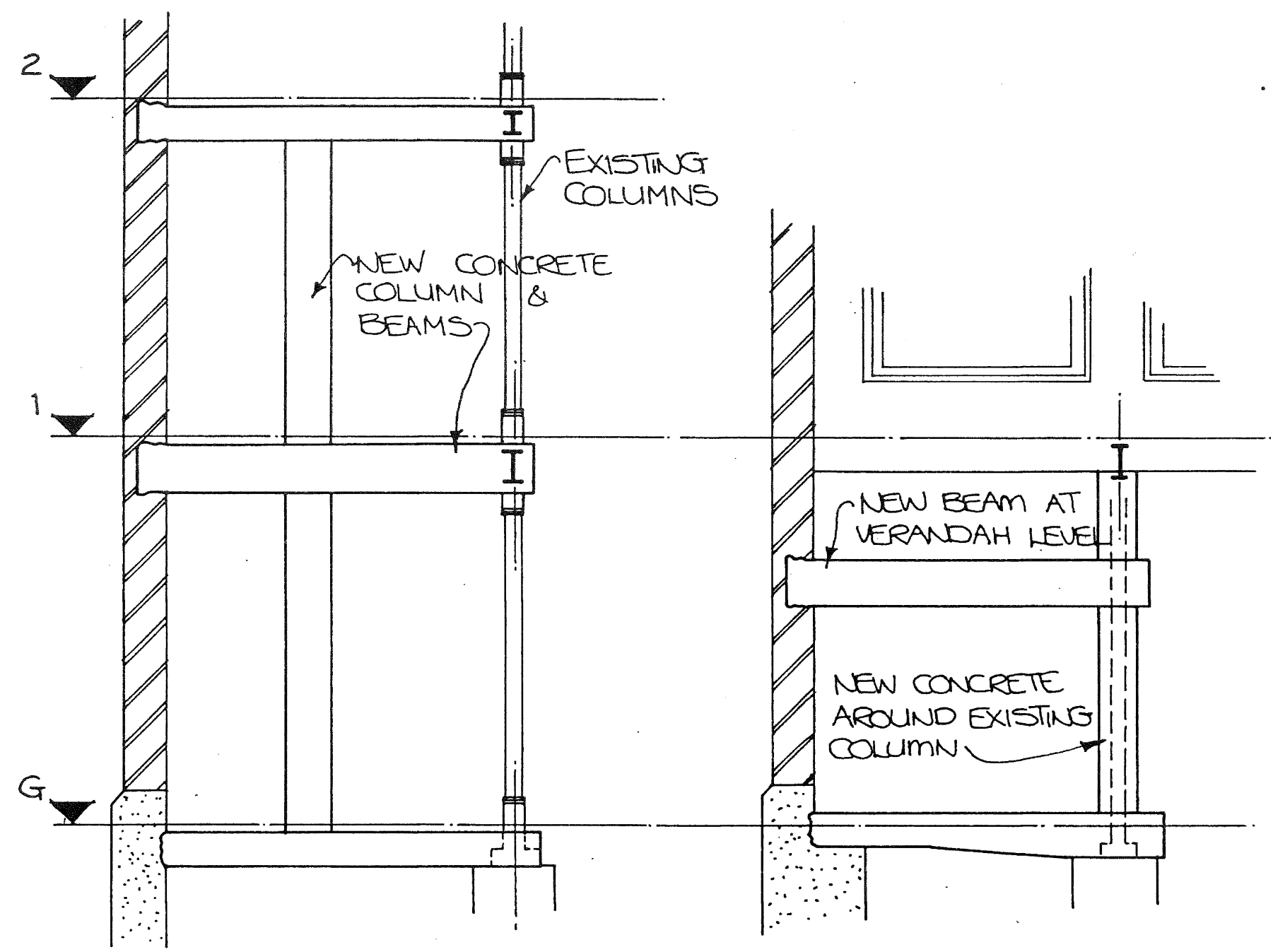

Frame A

FRAME B

FIGURE 2

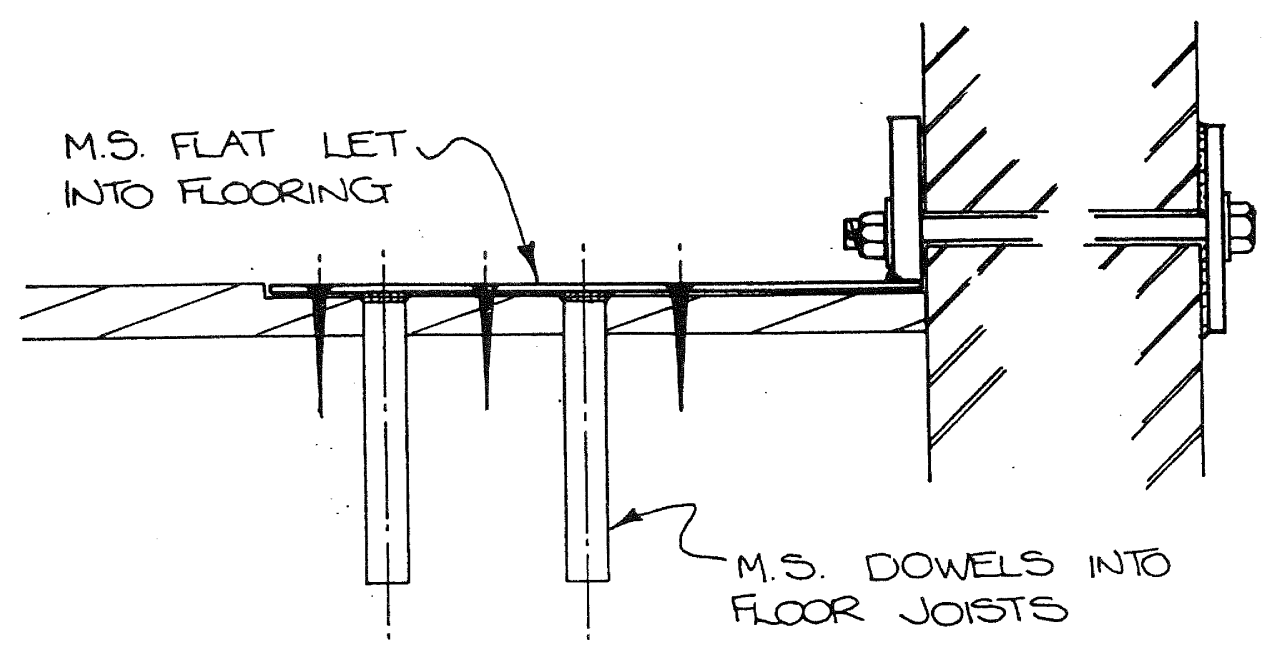

WALL TIE 